Original research article

Received: 19 September 2019

https://doi.org/10.20901/pm.56.3-4.08

\title{
Russia's Foreign Policy Evolution in the New Balkan Landscape
}

\author{
EKATERINA ENTINA \\ National Research University Higher School of Economics, Moscow \\ Institute of Europe, Russian Academy of Sciences \\ ALEXANDER PIVOVARENKO \\ Institute of Slavonic Studies, Russian Academy of Sciences
}

\begin{abstract}
Summary
The article reflects on the issue of the foreign policy strategy of modern Russia in the Balkans region. One of the most significant aspects of this problem is the difference in views between Russia and the West. Authors show how different interpretations of the events in former Yugoslavia in the 1990s and the beginning of the 2000s predetermined the sense of mutual suspicion and mistrust which spread to other regions such as the post-Soviet space. Exploring differences between the Russian and the Western (Euro-Atlantic) views on the current matters, authors draw attention to fundamental differences in terminology: while the Western narrative promotes more narrow geographical and political definitions (such as the Western Balkan Six), traditional Russian experts are more inclined to wider or integral definitions such as "the Balkans" and "Central and Southeast Europe". Meanwhile none of these terms are applicable for analysis of the current trends such as the growing transit role of the Balkans region and its embedding in the European regional security architecture. Therefore, a new definition is needed to overcome the differences in vision and better understand significant recent developments in the region. Conceptualizing major foreign policy events in Central and Southeast Europe during the last three decades (the 1990s, 2000s and 2010s), authors demonstrate the significance of differences in tools and methods between the Soviet Union and the modern Russia. Permanent need for adaptation to changing political and security context led to inconsistence in Russian Balkan policy in the 1990s. Nevertheless, Russia was able to preserve an integral vision of the region and even to elaborate new transregional constructive projects, which in right political circumstances may promote stability and become beneficial for both Russia and the Euro-Atlantic community.
\end{abstract}

Keywords: Balkans, Croatia, EU, NATO, Russia, Serbia 


\section{Introduction}

Fast-paced regional developments taking place in the international system have led to a reshaping of national borders, conflicts, regime change, and the setting of new international precedents, resulting in new and varied interpretations of historical and political processes. As Western scholarship has looked at the changes of regime and governments in Croatia and Serbia in 2000 as the beginning of democratisation and "normalisation" in the region (Buzan, Waever, 2003), the Russian scholarship sees this as the methods employed to arrange a coup d'état or an "orange revolution" (Ponomareva, Rjabinin, 2017).

These divergent views between Western and Russian scholarship set difference of interpretation and perception of what was happening in the former Yugoslavia region in the 1990s and is happening now. Although both the West and Russia declare their commitment to the stabilisation and integrity of borders as they were shaped in the 1990s, in fact, finding common ground is impossible because of the irresolvable issues related to international precedents, such as Kosovo and other precedents concerning the controversy between the principles of self-determination and territorial integrity.

For instance, Russia does not accept the Western interpretation of the 1999 Kosovo crisis which insists on the right of the ethnic minority group to rebel against central government. On the other hand, the Kosovo precedent as well the US intervention in Bosnia in 1995, gave Russia a reason to name its actions in Georgia in 2008 (regarding the protection of autonomy of South Ossetia and Abkhazia as well as the non-Georgian population of these autonomies) as a "peace enforcement" operation. ${ }^{1}$ Overall, methods and tools used by Russia might be regarded, to a large extent, as a "freestyle rethinking" of the concept of humanitarian intervention and peace enforcement, born in Bosnia in 1995 (operation "Deliberate force") and in Kosovo in 1999 (operation "Noble Anvil"). The Crimea case of 2014, in this regard, might be seen as a contribution to a further rethinking of a peacekeeping concept, started, though, by UN-NATO peacekeeping missions in the 1990s.

Russia's actions in the post-Soviet space (as well as Russian involvement in Syria) have given rise to quite reasonable (but overblown) fears that Russia might want to project its influence to the other regions in the world, especially to the Balkan region. Naming Russia a threat ${ }^{2}$ became a pretext for the EU and NATO to stir up their activities in the Balkans. The Berlin process was launched to bring the

1 Хроника вооруженного конфликта в Южной Осетии (август 2008 года). РИА-Новости. 08.08.2008. URL: https://ria.ru/20180808/1526017409.html (date of query: 10.08.2019).

${ }^{2}$ Merkel Concerned about Russian Influence in the Balkans. Spiegel Online. 17.11.2014. URL: https:/www.spiegel.de/international/europe/germany-worried-about-russian-influence-inthe-balkans-a-1003427.html (date of query: 16.08.2019). 
countries in the region closer to the EU. NATO's increased activity has weakened Russia's position, especially in Montenegro, which was fast-tracked into NATO membership in the summer of 2017 , becoming its $29^{\text {th }}$ member.

These blows happened as Russia began to review the Balkans' place in its foreign policy concept. The new concept does not mention the Balkans as a global player at all. Instead, it features such definitions as "Europe" and the "Euro-Atlantic Space". Nevertheless, this does not mean that the region has completely lost its relevance to Russian foreign-policy makers, but, rather, it points out that the perception of its borders has changed, and that the new framework for Russia's presence in Southeast Europe is beginning to take shape.

In addition to the Introduction and Conclusion, this paper consists of two main sections. The first section focuses on the geographical definition of the Balkans region and considers some of the approaches that are being used in Russian academic and foreign policy communities. Also it proposes a new definition of the region (the "Four-Seas Region", рус. "Четырехморье») that might be applicable in reflecting the actual developments that have been occurring since 2014. The second part analyses the imperatives of Russian foreign policy in three time periods (the 1990s, 2000s and 2010s) and presents some quandaries that may exist in Russia's foreign policy planning in the Southern Four-Seas Region in the near future.

\section{The New Balkan Landscape}

In order to understand the place of the Balkans on the Russian foreign policy priority list, one has to outline the geographical boundaries of the region. This task has traditionally been very challenging for researchers. An existence of a great number of countries (from Italy and Austria in the west to Turkey in the south-east) involved in the region's historical and political processes, both inside and outside the region, as well as a great number of dividing lines (historically not only between states but between imperial structures, integration projects, spheres of interest and even civilization areas) even now makes it impossible to talk about clear boundaries in the same categories like, for example, in Scandinavia. As a rule, researchers use a set of provisional notions, such as the Balkans, Southeast Europe, Western Balkans, Western Balkan Six, including different sets of countries depending on the political contextualisation. Some of those notions are traditional for the Russian academic discourse. Others such as the Western Balkans and Western Balkan Six are borrowed from Western scholarship and political narratives, and are de facto used by some representatives of Russian expert and analytical community.

Another question is whether the Balkans (Southeast Europe) can be classified as a separate region. The theorists (scholars) from the Copenhagen School, Barry Buzan and Ole Waever, answered this question negatively in the early 2000 s be- 
cause there were no strong regional or global powers here, which would be the key political and security "stakeholder" (like the USA in the Western hemisphere and Russia in the post-Soviet territory). The military conflicts of the 1990s were interpreted by Buzan and Waever as an attempt to create an autonomous regional security architecture, the central element of which, evidently, should have been the State Union of Serbia and Montenegro. International military intervention put an end to such attempts in 2000, and the regime change in Serbia (and in Croatia) was viewed as a step towards a more "European" ("normal") order of things (Buzan, Waever, 2003: 377-378, 395-396).

Therefore, in the early 2000s, the Copenhagen School theorists described Southeast Europe as a sub-region, and as an integral part of the European regional security architecture. For them, the "Balkans" consisted of 8 countries: Croatia, Bosnia and Herzegovina, State Union of Serbia and Montenegro, Macedonia, Albania, Bulgaria, Romania and Greece. "Southeast Europe", according to them, included 12 countries: the "Balkans" plus Slovenia, Hungary, Turkey, and Cyprus (ibid.: 379).

The most commonly used concept among the Russian academia (namely, modern history, international relations, regional studies, and economics) is the concept of Central and Southeast Europe. It encompasses the countries of the former Yugoslavia, Visegrád Group, Bulgaria, Romania and, to a certain extent, Albania and Slovenia. This concept appeared during the "Cold War" and included all the countries which embraced the socialist way of life. In the late 1990s - early 2000s, the term Central and Southeast Europe was still in use. Researchers continued to put these countries in the same group for the purposes of studying the processes of economic transformation (Центрально-Восточная Европа, 2018) and in an attempt to find commonalities related to their political transformation (ЦентральноВосточная Европа, 2015).

Grouping them according to this principle left out such important players as Greece and Turkey, both of which fell under British and American influence and joined NATO in 1952 from the concept of Southeast Europe. What is also important, is the civilisational component, meaning that the notion of Central and Southeast Europe included mostly Slavic countries. On the other hand, Hungary, Albania and even the Baltic States might be also included in the definition Central and Southeast Europe in its wider meanings.

It should be emphasised that the notion of Central and Southeast Europe (leaving out Greece and Turkey) is typical of research focusing on the problems of the later part of the $20^{\text {th }}$ century. If we look at the Balkan research of the $18^{\text {th }}-19^{\text {th }}$ centuries, or the first half of the $20^{\text {th }}$ century, then the notion of the "Balkans" would stretch from the Danubian Principalities in the East (Moldavia and Wallachia) to 
Greece in the South, including, naturally, the area where the Austrian Empire comes close to the Ottoman Empire (Виноградов, 2004: 1-6). Therefore we can conclude that the academic understanding of the region adapts to the current political dynamics and reflects the challenges faced by the academic community during a given historical period.

Today, we are confronted with new challenges to which we have to adapt for the following reasons: firstly, the breakup of the socialist bloc and the emergence of a whole new group of countries, instead of two federations, Czechoslovakia and Yugoslavia, which highlighted the differences in the political systems and culture. Today we cannot compare the processes of social, economic and political development, for example, of Poland and Romania or Bulgaria and Bosnia and Herzegovina. Analysis of the current events within the sub-regional structures (for instance, the analysis of events in the Serbia-Macedonia-Kosovo triangle) are difficult to apply to the analysis of the relationship structure within the Visegrád Group.

Secondly, the completion of the economic transformation process in the countries of Central and Southeast Europe resulted in a deepening gap between Central European countries (the Visegrád Group as well as Slovenia and Croatia) and less prosperous Southeast, sub-regional countries (including the "Balkan Six", Romania and Bulgaria).

Thirdly, there is a political demand to bring the Russian academic community in line with the policy makers in order to boost the quality of the country's foreign policy. Southeast Europe is within the scope of The $4^{\text {th }}$ European Department of the Russian Foreign Ministry. ${ }^{3}$ It deals with 12 countries: the "Balkan Six" (Albania, B\&H, Serbia+autonomous Kosovo, Macedonia, and Montenegro), members of the latest European extensions (Slovenia, Bulgaria, Romania, Cyprus, and Croatia), as well as Greece and Turkey. Central European countries are dealt with by The $3^{\text {rd }}$ European Department of the Ministry of Foreign Affairs. This division goes back to the times of the Russian Empire when the Balkan affairs were the responsibility of the Asian Department of the Foreign Ministry, while the European countries fell under the responsibility of a separate department. ${ }^{4}$ This might have been the reason why in 1946, when the Soviet Ministry of Foreign Affairs was founded, Greece and Turkey were not "separated on paper" from Yugoslavia, Bulgaria, Hungary, Romania, and Albania, and were also put on a watch list of a separate FM department.

3 http://www.mid.ru/about/structure/central_office

${ }^{4}$ Since 1832 the Department of External Relations dealt with European affairs and in 1847 it was turned into the Special Administration at the Ministry of Foreign Affairs. Asian affairs were the subject of operations of the Asian Department of the Ministry of Foreign Affairs of the Russian empire created in 1819 . 
This bring us to a conclusion, that one of the oddest things in describing the Russian foreign policy vision since the early 1990s, is the gap in understanding the regional complexities. The advent of a new geographical term, which reflects the course and nature of current political trends featuring its dynamic nature and the increasing presence of large international actors seeking to secure a strategic foothold in the region, may become a step towards developing a specific foreign policy strategy among extra-regional global actors and a deeper academic and scholarly understanding of these processes.

\section{New Geographical Positioning of the Region}

Based on the fact that 9 out of the 11 countries of the region (except Serbia and Northern Macedonia) have access to one of the four seas (the Adriatic, Ionian, Aegean, and the Black Sea), it appears reasonable to use the term "Four-Seas Region" (рус. "Четырехморье»). An alternative term may be "Southern Four-Seas Region" (рус. «Южное четырехморье»).

Unlike many terms currently in use, the term "Four-Seas Region" is the least abstract. Unlike the term "Balkans", it describes more clearly the geographical outline of the region clearly leaving beyond its borders the countries of Central Europe, specifically, the Visegrád Group, the majority of which have land borders. It reflects most appropriately the functional feature of the region's geography - namely, the long coastline, running to more than $16700 \mathrm{~km}$ (not including the numerous Croatian islands). Finally, the Four-Seas Region most suitably reflects a number of the geographical and historical features typical of this region: its connection to the Mediterranean basin and the actors historically present in it (Italy, Turkey, the UK and the $6^{\text {th }}$ fleet of the US navy). The term "Four-Seas Region" may be used for analysing the political activity in and around China, which has established (or is establishing) its investment presence in Greece, Macedonia, Albania, Croatia, and Serbia. The term "Four-Seas Region" reflects Russia's historical interests in this area whose strategic priority has been access to the Mediterranean Sea via the Balkans in order to expand its export opportunities and projection of power since the early $18^{\text {th }}$ century.

The new term also reflects the fact that, after the end of the "Cold War" and the disappearance of the "Iron Curtain", Greece and Turkey became involved in the Balkan affairs politically, socially and economically. For Greece, its "return" to the Balkans took place in 1993, which was marked by the problem of neighbouring country's name - Macedonia. The state failure crisis in Albania in the 1990s resulted in a labor migration to Greece, which was estimated to include as many as 480000 people in $2011 .^{5}$ The migration crisis of 2015 clearly demonstrated the

5 https://minorityrights.org/minorities/albanians/ 
link between Greece and Turkey and other neighbouring countries in matters of logistics and how they are intertwined in the context of humanitarian challenges. Finally, Greece joining the rest of the Balkans is part of the EU conceptual planning: according to the European Union Macro-Regional Strategy, Greece, together with Italy and former Yugoslav republics, belongs to the Adriatic-Ionian (rather than Mediterranean) macro-region, which exists alongside the Baltic, Danubian and Alpine macro-regions (European Commission). Trans-regional transport system modernisation projects (Corridor X) do not exclude Greece at all; on the contrary, they make it the final destination of a long transit route. So, if the Balkans have become closer to Europe, Greece has become closer to the Balkans.

As far as Turkey is concerned, it has been involved in the Balkans since the beginning of the 1990s by participating in stabilisation missions in Bosnia and Kosovo, growing investment and product turnover. From 2002 to 2016, the turnover of commodities between Turkey and the countries of the region grew from 3.6 billion USD to 16.2 billion USD (Ekinci, 2017: 9), additionally to infrastructure projects, such as the Belgrade-Sarajevo highway. The significance of Turkish cultural influence is clearly expressed in the building of mosques and cultural centres throughout the region (the largest ones are in Bar, Montenegro and Tirana, Albania). The Turkish ethnic community, according to official data, may comprise around 100 thousand people across 9 countries (Buyuk, Clapp, Haxhiaj, 2019). Possibly, the key factor connecting Turkey with the Balkan peninsula is the gas-transport routes. Two gas pipelines at once - TurkStream (planned to bring into operation in late 2019-middle 2020) ${ }^{6}$ and TANAP (launched on 12 June 2018) - tapping into the TAP pipeline (the construction of which in Greece and Albania is now $88 \%$ complete). ${ }^{7}$ Therefore, Turkey will potentially collect in its territory the main energy assets of the region, granting the country considerable influence over the Balkan energy sector.

A clear link between the Turkish and the Balkan issues is evident from the conflict on the Cyprus gas dispute. The statement made by Cyprus in August 2019 that it is going to veto the EU enlargement in the Western Balkans if the EU does not help Cyprus in a dispute with Turkey shows that the Eastern Mediterranean agenda is getting closer to the Balkans (Greek Cyprus..., 2019).

Perhaps, uniting Southeast and Central Europe into one group will acquire relevance in the mid-term, if one of the Central European infrastructure projects is implemented and the territory from the Baltic to the Adriatic Sea becomes one common space. Today, we can single out several such projects, including the EU strategy to create a network of gas inter-connectors as part of the Three-Seas Ini-

\footnotetext{
6 https://www.gazprom.com/projects/turk-stream/

7 https://www.tap-ag.com/pipeline-construction/project-progress
} 
tiative (Cross-Border Energy Cooperation..., 2018: 10), the EU strategy to turn the Danube into a single transport space (Danube Connectivity), the modernisation of Corridor X, the Chinese $16+1$ format. However, these processes are not pre-determined. The shortage of structural initiatives on the part of the EU, the deepening gap between "more successful" and "less successful" countries (the concept of "two-gear Europe"), strengthened competition between China and the US and its winding up to a zero-sum game logic - all that may slow down the integration processes in Southeast Europe and put their EU membership on hold. Therefore, the differences between Central Europe and Southeast Europe will deepen, which will bring the "Four-Seas Region" concept to the fore, which includes those countries worst hit by political, humanitarian and economic challenges in the past 28 years.

\section{Russia's Strategy in the Four-Seas Region}

\section{Russia's Strategy in the 1990s}

In order to understand Russia's strategy in the region in the 1990s, 2000s and 2010s, it is necessary to say a few words about the general logic behind Russia's foreign policy today. This appears important because very often Western experts and politicians habitually perceive Russian foreign policy as a reflection of Soviet diplomatic practices, and sometimes even as an attempt to reincarnate the Soviet Union; however, a number of key factors prove to the contrary of this perception.

Indeed, Russia declared itself not to be the successor of the USSR, but, rather, its follower. Having assumed this role, Russia undertook the task of single-handedly paying off all of Soviet debts, but also remained a permanent member of the UN Security Council (with the right to veto), kept all its nuclear weapons, inherited all the foreign assets, membership in all international organisations where the USSR had been a member, and remained signatory to all its international treaties.

One can say that de facto, under this scheme, all the other republics left the USSR, but Russia did not, even though it agreed to the Soviet Union's self-liquidation. It seems that the Russian Federation gave up the socialist ambitions and planned economy and, at the same time, inherited all the international legacy of the Soviet Union and its international posturing. Maybe this is the cause of many problems that Russia is now facing internationally. However, as far as the country's foreign policy goes, Russia gave up, consciously or unconsciously, most of the powerful tools formerly used by the USSR.

During the Soviet era, the communist ideology practiced by the state had an enormous "soft power". Around it, the USSR brought on board the whole of Eastern Europe. It built the socialist camp. It brought the socialist countries into the Warsaw 
Pact, Cooperation and Mutual Assistance and the Council for Mutual Economic Assistance. It roped in a large group of Asian, African and Latin American countries through the socialist development concept.

Having abandoned the USSR's ideological baggage, Russia could not, and would not, try to preserve the systemic mechanism of influence on international affairs which the USSR had used. The Soviet Union had always viewed diplomacy as a minor tool. The party-to-party ties played the most important role. The USSR was a partisan state in which power and resources were concentrated in the hands of the party elite. All socialist camp and socialist allegiance countries worked by the same rules. The nexus between party elites ensured, globally, efficient and effective international ties. Via the international party channels, the USSR could facilitate critical decision-making, coordination and unity of efforts. Since the creation of the CIS, the tendency to establish cooperation through special relationships with the party and government leaders remains. But these tools are not as powerful as they used to be. Dominance of party relationships in the power hierarchy pre-determined the importance of global networks of influence of that time - the Communist International and close interaction with the communist parties of Western countries. Moreover, the USSR had at its disposal non-governmental organisations, both national and international. All the pro-Soviet political powers had their own mass media. They were used as propaganda channels. They were the tools of influence.

Modern-day Russia has vague inter-party relations. Having no special ideology of its own, it has not been able to create global party networks under its auspice. That task was not even considered. And it profited very little from joining the party projects and unions of other countries. Besides, Russia is still largely a misfit in global party structures. USSR-led international intergovernmental organisations have long been disbanded. International non-governmental organizations either fell apart or work autonomously. There is no foreign mass media at a global level controlled by Russia. Therefore, despite the fact that Russia inherited the international legacy from the USSR and de facto owns it, it cannot be applied in practice, because it is either impossible or counterproductive.

The various outcomes of the "Cold War" and the different perception of these outcomes by Russia and the West, seriously affected the formation of the European, specifically, the Balkan line of Russian foreign policy after the breakup of the USSR. The end of the "Cold War" and the trust in the "gentlemen's agreement" over the non-expansion of NATO achieved in Malta by Mikhail Gorbachev, the desire to return to the Western cultural, philosophical and social community, which Russia historically considered itself to be part of, and de facto was (for example, Russia's role in the Concert of Europe of the $19^{\text {th }}$ century), shaped Russia's attitude towards the Yugoslav crisis. Because of these assumptions, the traditional Soviet 
instruments, political and ideological pressure and the projection of military force, were no longer in the Russian arsenal.

The functional difference between these two components must be underlined. As the political influence exercised via a global communist party network was practically impossible because of anti-communist politicians who came to power in the majority of Central-European and East-European countries, Russia still possessed some military capabilities (despite the withdrawal of the Western Task Force from Germany in the early 1990s).

The proof of such capabilities is the forced march conducted by the Russian peacekeeping forces to Pristina in June 1999, which may be tactically explained as an attempt to obtain its own sector in the peacekeeping mission in Kosovo, which was still being developed at the time. By doing so, Russia was hoping to get what it failed to get in Croatia and Bosnia and Herzegovina, where de jure and de facto Russian peacekeepers were under NATO command. However, the Russian peacekeeping mission was not to continue and came to an abrupt end in 2003. This was the result of the lack of technical capabilities for sustaining its forces and the fact that in the early 2000s (same as in the early 1990s), Russian leaders, headed by V. Putin chose a path of cooperation with the US. This time, the stakes were on building a united front against international terrorism.

On the whole, the Russian policy in the Balkans in the 1990s was frequently characterised by Russian researchers as dependent, inconsistent and traitorous in relation to the Serbs who were seen as the pillar of the Russian influence in the Balkans (Никифоров, 1999: 25). Not denying this point of view, we would like to note that this policy did bear some fruit.

The critical principle of the new Russia's foreign policy in the Four-Seas Region was that Moscow did not have any objections against the recognition of the republics which chose to leave the former Yugoslavia. Recognition by Moscow of the independence of Slovenia and Croatia provided the foundation for the development of normal intergovernmental relations with these countries starting from the second half of the 1990s until the first half of the 2010s. Russia supported, on the diplomatic level, the complex process of Skopje obtaining its independence and joining various international organisations (specifically, the Council of Europe).

Despite the fact that in June 1992 Russia introduced sanctions against the State Union of Serbia and Montenegro (Resolution No. 757 of the United Nations Security Council) and on the whole implemented a disappointing policy with regard to the Serbs in the 1990s (who traditionally view Russia as their protector and ally), it quite quickly managed to restore its authority. The U-turn of the plane carrying E. M. Primakov over the Atlantic in 1999, Moscow's negative view of NATO forces bombing Serbia and Montenegro, and the march of the Russian paratroopers to 
Pristina and occupation of the Slatina airfield returned Russia into the public discourse as a consistent protector of Serbian interests. Despite the fact that the events of 5 October 2000 are seen in Russia as one of the first "orange" revolutions, it was Moscow who was able to persuade S. Milošević to recognise the results of the 5 October 2000 events and the victory of democratic opposition. Then the foreign minister Ivanov was one of the first to congratulate V. Koštunica during the presidential elections. All of this enabled Russia to regain its position in the region. Having said that, despite the fact that the 1992 sanctions froze political, economic, scientific and cultural connections with Belgrade, the period of the 1990s paradoxically returned the emotional closeness between the nations, helped to overcome the negative background existing during the "Cold War", and laid the foundation for intergovernmental bilateral Russian-Serbian relations which resulted in signing the 2013 Declaration of Strategic Partnership (Декларация..., 2013).

\section{Russia and the EU in the Four-Seas Region in the 2000s and 2010s}

During the first half of the 2000s, it was typical of Russia's foreign policy to see the European Union as a successful integration project. At the same time, before 2010, Russia had a lack of desire in implementing its own integration project. It is wellknown that the project of the Eurasian economic union was firstly presented by the president of Kazakhstan Nursultan Nazarbayev in 1994 during a speech at Moscow State University, but the project was then put off discussing for 16 years.

As a result, Russia encouraged the Balkan countries' desire to join the EU ignoring the fact that European integration can go hand-in-hand with NATO membership. For that reason, Moscow turned a blind eye towards Albania and Croatia joining NATO, which, in today's context, may be seen as a hostile move. Having backed down from resolving regional security issues (except working in the UN Security Council on the issue of Kosovo and in the B\&H Contact Group), Russia placed its bet on developing pragmatic, primarily economic relations with the region.

However, at the same time, relations between Russia and the West were gradually growing sour. The political starting point for this new spiral of tension is conventionally seen in V. Putin's Munich speech (10 February 2007) and the armed conflict in South Ossetia (7-16 August 2008). Another dividing point became the Ukrainian crisis. On 6 May 2014, the future president of Croatia, then acting Deputy Secretary General of NATO Kolinda Grabar-Kitarović, on her facebook page expressed support for Ukraine in connection with "Russian aggression". ${ }^{8}$ Simul-

${ }^{8}$ Kolinda pred Ukrajinskim Barikadama. Hrvatska dužnosnica NATO-a slikala se na poprištu revolucije. Jutarnji List. 06.05.2014. URL: https://www.jutarnji.hr/vijesti/hrvatska/kolindapred-ukrajinskim-barikadama-hrvatska-duznosnica-nato-a-slikala-se-na-popristu-revolucije/797554/ (date of query: 16.08.2019). 
taneously, Germany initiated the Berlin process aimed at strengthening the EU's position in the Balkans. At the end of 2014, Bulgaria's non-constructive position put the South Stream project to an end. In autumn 2015, under the pretext of an attempted (alleged) coup d'état, consolidation of Montenegro's political efforts took place. These events resulted in Montenegro joining NATO on 5 June 2017. In parallel, Serbia started leaning considerably towards the Euro-Atlantic alliance, by signing a logistical support agreement (NSPO Agreement) with NATO and hosting joint military exercises with the US and NATO (Double Eagle-2017 and Srbija-2018).

How can we assess the Russian economic presence in the Four-Seas Region in this political context? First of all, it cannot be denied that from the end of the 1990s to 2012-2013, Russia implemented a number of strategic investment projects which strengthened its presence in the region. The "point of entrance" was Bulgaria and Romania. In 1998, Russia bought the controlling stake in the local oil refineries (Petrotel in Romania and Burgas in Bulgaria), followed by the 3 billion USD worth of investments in the Bulgarian economy. In 2005-2008, Russian companies Lukoil, Zarubezhneft and Gazprom obtained a presence in Serbia, Macedonia, and Bosnia and Herzegovina (Republika Srpska) by purchasing local companies (Bosanski Brod refinery, Naftna Industrija Srbije). On 15 February 2012, with acquiring Volksbank International financial group, the Russian Sberbank gained presence in seven countries of Central and Southeast Europe (the Czech Republic, Hungary, Slovenia, Bosnia and Herzegovina, Croatia, Serbia, Ukraine). On 23 May 2013, Serbia and the Russian Railways signed an agreement for modernisation of railways planning to upgrade six sections of railway with the total length of $111 \mathrm{~km}$, along with the purchase of Russian diesel trains.

It was not only Serbia which felt the dynamics of cooperation. Slovenia is the only republic of the former Yugoslavia which has a positive foreign trade balance with Russia. The share of Slovenian export to Russia accounts for 3.4\%, which is considerably higher than the share of Germany, Italy and Hungary (about 1.9-2\%). ${ }^{9}$ It is quite logical that, despite supporting anti-Russia sanctions, Slovenia also consistently promoted resuming the dialog with Russia. The visit of Russian President V. Putin to Slovenia on 30 July 2016 made Slovenia, together with Hungary, one of the EU countries that broke the circle of diplomatic isolation which started to form in the spring of 2014.

As the topic relates to Croatia, relations developed according to a slightly different scenario. A pragmatic bilateral relation got off to a good start during the late $1990 \mathrm{~s}$, followed by continued cooperation in the area of investment and tourism, growing until 2012-2013. A failure of a number of ambitious projects (such as the purchase of some companies in Croatia by the Russian company Mechel) and

${ }^{9}$ https://oec.world/en/profile/country/svn/ 
negative effect of the EU sanctions against Russia (the trade turnover between two countries reduced by almost half comparing to figures before 2014) to a large extent showed the limits for Russian presence in Croatia later on. ${ }^{10}$ Nevertheless, it is still considerable thanks to Fortenova (former Agrokor) where the Russian Sberbank and VTB, according to the results of the 2018 restructuring, are major shareholders (39.2\% and $7.5 \%$ respectively). ${ }^{11}$

Looking back at the relationship between Russia and the EU in the Four-Seas Region one notices an amazing fact: despite the growth of political tension, Russian business was able to expand without any barriers from Brussels. A good illustration of this is the fact that a 600 million EUR loan was granted by Sberbank to Agrokor in April 2014, three weeks after the Republic of Crimea joined Russia and the first package of sanctions was introduced by the European Union. It is hard to understand today whether such odd cases are the result of inflated expectations, ungrounded hopes, strategic short-sightedness or tactical miscalculations both in Moscow and in Brussels. It is also quite interesting to understand the reasons why such Russia's vast economic presence became possible.

It is difficult to deny that Russian investments benefited the recipient countries substantially. They made up for the shortage of Western investments in fundamental infrastructure, they contributed to restoring enterprises damaged as a result of the military and economic shocks of the 1990s, they enabled the modernisation of production. It is sufficient to note that the productivity of the Brod refinery, which resumed its operations in 2008, grew from 1.2 million tons to 3 million tons per year by 2011. The building of Banatski Dvor underground gas storage led to the creation of new infrastructure in Serbia. The Serbia-Russian Railways partnership based on the loans provided by Russia to Serbia enables the improvement and modernisation of Serbia's railway lines (which have always been a weak spot in the Balkans). The presence of the Russian railway monopolist meets the interests of both the European Union which wants to upgrade the key transport corridor and of the Russian Railways, for which Serbia, just like South Africa, Iran, Vietnam, Indonesia, and the EAEU countries, is a country where Russian Railways are modernising and improving infrastructure.

Another key circumstance is that at the time they had virtually no competition from Western-European capital, which in the 2000s and 2010s refrained from

10 Sankcije prepolovile hrvatski izvoz u Rusiju, pogledajte tko su najveći gubitnici. Tportal.hr. 17.04.2018. URL: https://www.tportal.hr/biznis/clanak/sankcije-prepolovile-hrvatski-izvoz-urusiju-pogledajte-tko-su-najveci-gubitnici-foto-20180417 (date of query: 16.08.2019).

11 Российские госбанки получат почти половину крупнейшего ритейлера Хорватии. Ведомости. 04.07.2018. URL: https:/www.vedomosti.ru/business/articles/2018/07/04/774656gosbanki-horvatii (date of query: 16.08.2019). 
any industrial investment when its position in the financial sector was weakened by the 2008 financial crisis. As a result, the opportunities presented for Russian capital strengthened Russia's political foothold. Undoubtedly, Russian investments helped win back the leader of Republika Srpska, Milorad Dodik, who started his career in the beginning of the 2000s as a politician the EU and US were betting on (Энгельгардт, 2015: 176-177). Although Moscow has no illusions regarding the pro-Russian frame of mind of Serbian leader Aleksandar Vučić (Саморуков, 2019), it cannot be denied that numerous contracts made between Serbia and Russia (same as with Germany, Turkey and, since recently, France) keep Serbia from making a leap towards the Euro-Atlantic.

The situation with Agrokor may be interpreted in a similar manner. Although representatives of Sberbank insist that they want to sell its share in the corporation, ${ }^{12}$ there are suspicions that the true motive of the Russian presence is to provide Russia with some leverage in the Eurozone which Croatia hopes to join in the near future. Although there has been talk about "suspicious" Russian investments since 2014, even in the current conditions, Moscow is still one of the few players ready to invest hundreds of millions of Euros in high-risk enterprises. It is quite possible that the situation will change over time - if the countries in the region are not able to provide friendly business environment that might attract Russian investment in the Four-Seas Region instead of in the other regions of the world or even in its own country.

\section{Russian Strategy Outlook}

What happened after 2014, proved yet another neo-Marxist maxim: elites in possession of political clout are capable of affecting economic processes too. Bulgaria came under pressure from the European Union, which resulted in Russia's decision to stop the South Stream project on 1 December 2014. The South Stream failure, which was largely seen as a key project for Russia (for which, to a large extent, a lot of the infrastructure and financial instruments were made), showed that an insufficient effort was put into the political component of securing the Russian presence in Bulgaria. On the one hand, this may be understood as evidence of fuzzy thinking (and sometimes even carelessness) of Russia's foreign policy makers in the 2000s, their refusal to bet on "soft power" (given that the technologies were far from perfect at the time). But it also may be interpreted as a hope that the Balkans may become the point of convergence between Moscow and Brussels.

12 Sberbank to Sell Stake in Croatia's Agrokor after Restructuring. Russia Business Today. 20.03.2019. URL: https://russiabusinesstoday.com/economy/sberbank-to-sell-stake-in-croatiasagrokor-after-restructuring/ (date of query: 10.07.2019). 
By conceding to the EU's conditions related to the Third Energy Package (a political requirement for diversification of the gas supply mechanism), Russia admitted the vulnerability of its position in the Balkans. The reaction to those events was the new Foreign Policy Concept of the Russian Federation adopted on 30 November 2016 in which the notions of the "Balkans" and "Southeast Europe" were excluded from the foundational documents. Instead, the new concept features such concepts as the "European Union", "European Region", "Euro-Atlantic Region" (Концепция внешней политики Российской Федерации, 2016).

Thus, the events of 2015-2016 resulted in a considerable reduction of Russian presence in the region. As a result, the Russian representatives have been increasingly expressing concerns about NATO's expansion in the Balkans. ${ }^{13}$ It should be noted that, under the current circumstances, the EU expansion also poses certain risks for Moscow because the EU common foreign-trade policy will most likely force the Balkan states to give up their trade with Russia (Саморуков, 2018). One of Brussels' information requirements for Serbia was to join the sanctions which would have naturally resulted in a reduction of commodity turnover $(7 \%$ of Serbian export and $6 \%$ of import to and from Russia - to the total of about 2.4 billion USD according to the 2017 data). ${ }^{14}$

Montenegro's joining NATO and Macedonia's upcoming membership did not result in an existential crisis of the Russian foreign policy and the damage to the reputation of Russian diplomacy was not as severe as it might have been. However, there is no doubt that Russia is reviewing the logic of its presence in the Balkans. Expert discussion is in progress. The traditionalist part of the expert field (mainly represented by those specialising in the Balkans) considers the Russian presence in the Balkans in the civilisational paradigm. It evaluates the necessity of a more active political presence in the region as an important transit region populated by people close to the Russian nation ethnically and culturally. Any form of forcing Russia out of the Balkans is unacceptable for this paradigm (Пономарева, 2017). The modernists represented by experts close to the Russian establishment think in more pragmatic categories. They claim that Russia's presence in the Balkans is associated more with problems and risks than opportunities. Additionally, the Balkans, with all their embedded problems, are the sphere of influence of the EU. Therefore, the absence of Russia in the region is not a geopolitical failure, but an opportunity to get rid of the "problematic assets" and to focus on pursuing its foreign policy interests in more promising areas of the world (Лукьянов, 2018).

${ }^{13}$ Foreign Minister Sergey Lavrov's interview with the German newspaper Rheinische Post, published on 18 July 2019. URL: http://www.mid.ru/en/web/guest/meropriyatiya_s_uchastiem ministra/-/asset_publisher/xK1BhB2bUjd3/content/id/3728756 (date of query: 10.07.2019).

${ }^{14}$ https://oec.world/en/profile/country/srb/ 
As can be seen, the principal point of differences between these two views are the Russian prospects in the Balkan peninsula from the point of view of its future in macro-regional configurations. Today, we observe a combination of contradictory trends: growing transit importance of the region with its marginalisation in a social, economic and political sense. Russia's attention to the region will depend on how these trends develop.

The realisation of the transit potential of the Four-Seas Region in connection with China's efforts to build a logistical chain to Europe is a shared ambition: published in the autumn of 2018, the EU Connectivity Strategy and modernisation of Corridor X demonstrate Brussels' desire to find a path to Asia.

The marginalisation problem is related to the urging of the European centre to protect itself from the threats coming from the Mediterranean, scale down the social and economic tension existing in the Balkans, while avoiding large financial costs and sudden political moves. Here, a whole range of questions are raised, which Russia also wants to answer. When can we expect new countries to join the EU (according to "Juncker's Plan")? What will the relations between Russia and EU be like in the mid-term (for example, in the middle of the 2020s)? The third, and not least important, question is whether the EU is capable of implementing a common foreign policy in relation to the countries of the region or will relations increasingly develop towards a conglomerate of national policies and bilateral (including behind-thescenes) agreements. The position of France and the Netherlands which are skeptical about the EU expanding in the Balkans contradicts the position of the pro-expansionists (for example, Italy). Expansion is also supported by the UK and the US, whose interests are not shared by the continental EU. Another important question is the attitude to religious extremism and the refugee problem, which is posed by certain political forces (such as Alternative for Germany). The answers to these questions overall will determine whether the Balkans will become full-fledged members of the European family with prospects of development or whether they are set to remain on the semi-periphery, a territory of competition among global players. The answers to these questions will undoubtedly determine the logic of Russia's actions in the coming period.

Viewing the Four-Seas Region as an integral system with its own connectivities, we can come to the conclusion that if Russia's presence in the region is brought to a minimum, which is what the EU is trying to achieve, this will not mean that all of Brussels' problems there will be resolved. Firstly, a certain closeness of Russia to the Balkan region will remain regardless. It will be supported by both the sense of historical and cultural unity and Brussels' objective interest in external investments. The companies engaged in modernising the transport infrastructure (Russian Railways in Serbia) will most likely continue their work. Besides, reducing the Rus- 
sian presence in the area is not a cure-all solution. Reducing the specific share of the Russian investment will result in a larger investment presence of China, Turkey, the US and other countries who are "external players" in relation to the EU. These countries may include the UK who is now considering expanding its own economic and political presence. Brussels will probably have to decide on its own which of these partnerships is most profitable for it and does not pose any threat.

However maybe in these circumstances partnership with Russia may become not as horrible as it has been depicted by a common narrative since 2014. By changing its position regarding Russian gas, Brussels informally admitted that without the Russian energy export it is difficult to procure the stability of the economies of the Four-Seas Region which suffer from a shortage of cheap energy. It is probably also a method of striking a balance between the US and Turkey, who are playing their own games in the region, thus destabilizing the situation (the Cyprus gas dispute) and China's continued economic expansion in Europe. It is hard to say anything definite about a TurkStream project before the end of the construction of the route via Bulgaria. However, if it becomes a reality, it will be able to close a whole range of differences dogging the relationship between Russia and the EU in recent years.

Moscow is placing a huge bet on TurkStream project scheduled to be launched in 2020-2022. ${ }^{15}$ Moscow's relatively quick agreement with the Third Energy Package requirements and the delegation of considerable powers related to transit to Turkey (which hopes to monopolize major regional logistical chains) was a forced step. It reflects Moscow's interest in expanding exports and the diversification of supply routes. Development of TurkStream, which started on 7 February 2015, nine years after closing the South Stream, demonstrates Moscow's high adaptability and flexibility in relations with the EU.

No matter what Russia's further actions are, it would be a gross simplification to consider its foreign policy within the logic of civilisational closeness. From 10 to $15 \%$ of Russia's population (according to different data) practice Islam. To some extent, the relationship between Russia and Turkey is better than its relationships with Orthodox Romania, Bulgaria, Montenegro, and Georgia whom Russia freed from the Ottoman oppression in the $19^{\text {th }}$ century. ${ }^{16}$ In this respect, the fact that Russia's strategic partners include Orthodox Serbia is rather an exception to the rule.

In this respect, a strategic partnership with Serbia based on economic cooperation, supplies of arms and other technical products is not a consequence of civili-

15 «Газпром» сделал трубный выбор. Восточная Европа подтвердила маршрут «Турецкого потока». Коммерсант. 22.11.2018. URL: https://www.kommersant.ru/doc/3806415 (date of query: 02.03.2020).

${ }^{16}$ In summer 2018 all these countries joined the demarche by Great Britain and expelled Russian diplomats due to "the Skripal case". 
sational and religious closeness, but rather a result of the foreign policy doctrine chosen by Belgrade, which states that its interests do not lie just in the West, but in the East as well.

When describing Russia's policy in the Middle East as an example, it should be mentioned that Russia is capable of maintaining working relationships with political players who have the exact opposite interests (Israel, Iran, Turkey, the Gulf countries). It is quite possible that we will see something similar in the Four-Seas Region one day. The meeting between Vladimir Putin and Hashim Thaçi on 17 November 2018 based on the mutual desire of both parties, demonstrates that Russia is not taking the Albanian direction off its agenda. Opening air traffic with Albania in the summer of 2019 (by Ural Airlines) shows that Russian private investment may not be limited to the Montenegro coast alone. Moreover, the relations between Russia and Albania, excluding the Kosovo issue, in recent years were to a least extent subject to diplomatic crises of all the Balkan countries and developed incrementally. Even now, unlike Brussels, Moscow is not inclined to see dividing lines in the region between EU members and applicants. The expansion of NATO may be bad news for the supporters of the civilisational theory, but it will also serve as a stimulus for Russian policy makers to find new, more creative ways of implementing the current foreign-policy doctrine aimed at strengthening sovereignty and boosting multipolarity.

\section{Conclusion}

Understanding foreign policy today, involves facing a certain number of methodological, political and existential challenges caused by the rapidly changing situation in the world since 2014, the Russia-West crisis, and the destruction of the status quo created in the 2000s.

Having faced the risk of losing all the achievements reached in the 2000s, Russia is developing a wider set of tools for implementing its own foreign policy. Russia's exclusion from the majority of political and economic processes in the European Union allows it not to be bound by ideological and opportunistic conventions. Among Russian foreign policy makers (as well as among Russian foreign policy thinkers) and academic community there is an understanding that Russia has a unique configuration of relations with each country in the Four-Seas Region, drawing on the similarities and differences of historic fate and fortunes, civilisational closeness, the scale of joint economic projects, and political interests. At the same time, with each of these countries Russia is bound by something more than just pragmatic economic interests and the political situation.

The potential of these relations is huge. It has not yet been fully understood or studied. One thing is beyond doubt: this potential is being poorly used, insuffi- 
ciently and inefficiently. Besides, Russia could give so much to the region in very different dimensions, both in terms of economic development and strengthening security, political stability, settling differences, and making peace between various ethnic groups.

If the circumstances change, this potential may remain untapped. However, that will require conscious efforts from both sides - both on the part of Moscow and on the part of the countries and political circles of the Four-Seas Region. We clearly need a new pro-active policy.

In the 1990s and 2000s, Russia simply trusted that joining the EU would solve all the problems in the Balkans. And partnership with the EU would serve as the guarantee of Russia's peaceful, positive presence in the region and the development of multifaceted and mutually beneficial connections. Unfortunately, none of that has happened. On the contrary, the opposition between Moscow and Brussels is projected on the regional matters.

Evidently, this trend must be turned around. All nations in the triangle RussiaFour-Seas Region-EU are interested in a shift of policy. But it will require giving up past taboos, ideas and prejudice, whoever supports them, and building a new future together.

\section{REFERENCES}

Buyuk, Hamdi Firat; Clapp, Alexander; Haxhiaj, Serbeze. 2019. Diaspora Politics: Turkey's New Balkan Ambassadors. Available at https://balkaninsight.com/2019/03/19/ diaspora-politics-turkeys-new-balkan-ambassadors/ (accessed 14 August 2019).

Buzan, Barry; Waever, Ole. 2003. Regions and Powers. The Structure of International Security. Cambridge University Press. New York.

Концепция внешней политики Российской Федерации [Concept of Russian Foreign Policy]. 2016. Available at http://kremlin.ru/acts/bank/41451 (accessed 6 August 2019).

Cross-border energy cooperation in Central Europe. 2018. CEEP Policy Paper. Available at https://www.ceep.be/policy-paper-cross-border-energy-cooperation-in-central-europe-towards-flexible-secure-and-sustainable-regional-energy-markets/ (accessed 15 August 2019).

Декларация о стратегическом партнёрстве между Российской Федерацией и Республикой Сербией [Declaration of Strategic Partnership between the Russian Federation and the Republic of Serbia]. 2013. Available at http://kremlin.ru/supplement/1461 (accessed 16 August 2019). 
Ekinci, Mehmet Uğur. 2017. Türkiye-Balkanlar İlişkileri. Available at https://www.setav.org/turkiye-balkanlar-iliskileri/ (accessed 15 August 2019).

Энгельгардт, Георгий Николаевич. 2015. Республика Сербская в Боснии и Гериеговине. Возникновение и эволющия (1990-2006 г2.). Диссертация на соискание ученой степени кандидата исторических наук. Институт славяноведения РАН. Москва. [Engelgardt, Georgi. 2015. Republika Srpska in Bosnia and Hercegovina. Genesis and Evolution (1990-2006). Dissertation for degree in History. Institute of Slavonic Studies, Russian Academy of Sciences. Moscow.] Available at https://inslav.ru/images/stories/other/2015_engelgardt_dissertacija.pdf (accessed 18 August 2019).

Greek Cyprus threatens to veto EU enlargement over row with Turkey. 2019. Available at https://www.dailysabah.com/eu-affairs/2019/06/18/greek-cyprus-threatens-to-veto-eu-enlargement-over-row-with-turkey (accessed 14 August 2019).

If Croatia joins the Eurozone, it would give Russia its greatest weapon in Europe. 2019. Available at https://www.euronews.com/2019/01/22/if-croatia-joins-the-eurozoneit-would-give-russia-its-greatest-weapon-in-europe-view (accessed 22 January 2019).

Куликова, Наталья Владимировна (ед.). 2018. Центрально-Восточная Европа 6 поисках новых источников развития. Институт экономики РАН. Москва. [Kulikova, Natalia (ed.). 2018. Central and Eastern Europe. In search for new potential for development. Institute of Economics, Russian Academy of Sciences. Moscow.]

Лукьянов, Федор. 2018. Ретро заказывали? За что на самом деле предложили голосовать жителям Македонии, Россия в глобальной политике, 02.09.2018. [Lukyanov, Fedor. 2018. Have you ordered retro? What was really proposed for voting to the citizens of Macedonia, Russia in Global Affairs, 02.09.2018.] Available at https://globalaffairs.ru/redcol/Retro-zakazyvali-19779 (accessed 16 August 2019).

Никифоров, Константин Владимирович. 1999. Между Кремлем и Республикой Сербской (Боснийский кризис: завершающий этап). Институт славяноведения PAH. Москва. [Nikiforov, Konstantin. 1999. Between the Kremlin and Republika Srpska. The Bosnian Crisis: Final Phase. Institute of Slavonic Studies, Russian Academy of Sciences. Moscow.]

Никифоров, Константин Владимирович (ед.). 2015. Центральная и Юго-Восточная Европа. Конеи XX - начало XXI вв. Аспекты общественно-политического развития. Историко-политологический справочник. Нестор-История. Москва, Санкт-Петербург. [Nikiforov, Konstantin (ed.). 2015. Central and South-East Europe. The End of XX-the Beginning of XXI Century. Aspects of Social and Political Development. Historical and Political Handbook. Nestor-Historia. Moscow, SaintPetersburg.]

Пономарева, Елена Георгиевна. 2017. Балканская политика Российской Федерации: в поисках потерянного времени?, in: 25 лет внешней политики России: сб. 
материалов Х Конвента РАМИ. 5 m. Т. 1. Внешняя политика России: глобальное и региональное измерения. В 2 ч. Ч. 1, с. 486-502. МГИМО-Университет. Москва. [Ponomareva, Elena. 2017. Balkan Policy of the Russian Federation: in Search of Lost Time?, in: 25 Years of Russia's Foreign Policy: Materials of X RISA Convention. In 5 parts, part 1. Foreign Policy of Russia: Global and Regional Dimensions. Chapter 1. MGIMO-University. Moscow: 486-502.]

Ponomareva, Jelena; Rjabinin, Jevgenij. 2017. Obojene revolucije u kontekstu strategije kontrolisanog haosa, Argumenti, (XI) 30: 45-60.

Саморуков, Максим. 2018. Противоречия России и ЕС на Балканах. В чем они и можно ли их преодолеть. Московский центр Карнеги, 19.12.2018. [Samorukov, Maxim. 2018. Disagreements Russia-EU in the Balkans. Where are they and how to overcome them. Moscow Carnegie Center, 19.12.2018.] Available at https://carnegie.ru/commentary/77961 (accessed 14 August 2019).

Саморуков, Максим. 2019. Почему Белград устал от российской поддержки. Московский иентр Карнеги, 17.01.2019 [Samorukov, Maxim. 2019. Why Belgrade is tired of Russian support. Moscow Carnegie Center, 17.01.2019.] Available at https://carnegie.ru/commentary/78146 (accessed 14 August 2019).

The European Commission website, section of Macro-Regional Strategies. 2017. Available at http://ec.europa.eu/regional_policy/en/policy/cooperation/macro-regionalstrategies/ (accessed 23 September 2017).

Виноградов, Владилен Николевич (отв. ред.). 2004. История Балкан. Век восемнадиатый. Институт славяноведения РАН. Москва. [Vinogradov, Vladylen (ed.). 2004. History of the Balkans. The Eighteenth Century. Institute of Slavonic Studies, Russian Academy of Sciences. Moscow.]

Mailing Addresses:

Ekaterina Entina, Department of International Relations, National Research University Higher School of Economics, Malaya Ordynka 17, 119017, Moscow, Russia.E-mail: e.entina@hse.ru

Alexander Pivovarenko, Institute of Slavonic Studies, Russian Academy of Sciences, Leninsky Prospekt 32-A, 119334, Moscow, Russia. E-mail: aleksandar.a.p@ya.ru 